\title{
Elimination of experimentally induced bovine intramammary infection assessed by multiplex real-time PCR and bacterial culture
}

\author{
Heidi Hiitiö, ${ }^{1}$ Satu Pyörälä, Suvi Taponen, Päivi Rajala-Schultz, and Heli Simojoki \\ Department of Production Animal Medicine, University of Helsinki, Paroninkuja 20, 04920 Saarentaus, Mäntsälä, Finland
}

\begin{abstract}
Diagnosis of bovine intramammary infection (IMI) has traditionally been based on bacterial culture, but currently IMI can also be detected with DNA based methods, such as multiplex real-time PCR. The aim of this study was to describe the elimination of bacteria in experimentally induced IMI on the quarter level, using conventional bacterial culture (BC) and multiplex real-time PCR. Two coagulase-negative staphylococcal species, Staphylococcus epidermidis and Staphylococcus simulans, were experimentally inoculated into 14 healthy quarters of 8 dairy cows during 4 consecutive study periods. Intramammary infections were followed with 20 milk samplings per each quarter. Milk somatic cell count was monitored to evaluate the inflammation process in the quarters. Four quarters cured spontaneously during the study period according to the culture. The PCR detected staphylococcal DNA from these quarters for several days after they were defined as cured in BC. Agreement between BC and PCR results varied from substantial to almost perfect agreement for the first $36 \mathrm{~h}$ postchallenge, decreasing to moderate levels toward the end of the sampling period. Based on this study, we recommend collecting possible follow-up samples to assess the bacteriological cure from IMI not until 2 to $3 \mathrm{wk}$ after the onset of mastitis or after the quarter milk somatic cell count has normalized when PCR is used.
\end{abstract}

Key words: bovine mastitis, multiplex real-time PCR, coagulase-negative staphylococci, experimental infection, elimination of microbes

\section{INTRODUCTION}

Conventional bacterial culture according to accepted diagnostic methods (Middleton et al., 2017) has served as the gold standard in mastitis diagnostics. The modern dairy industry would, however, benefit from new, faster diagnostic tools for the identification of mastitis-

Received October 4, 2017.

Accepted February 5, 2018.

${ }^{1}$ Corresponding author: heidi.hiitio@helsinki.fi causing organisms. Molecular techniques with different variations of PCR analyses have been introduced to mastitis diagnostics since the beginning of the 21st century (Phuektes et al., 2001; Gillespie and Oliver, 2005; Studer et al., 2008). The first commercial assay to challenge the gold standard was a multiplex real-time PCR designed to detect 11 microbes and the staphylococcal betalactamase gene (blaZ; Koskinen et al., 2009).

Multiplex real-time PCR used in mastitis diagnostics is based on a technique where specific parts of the genome from different microbial species are multiplied and detected simultaneously from a milk sample. The PCR assay test panel includes predesigned oligos for target gene sequences of certain microbial species that most commonly induce mastitis (Koskinen et al., 2009). In optimal conditions, the number of amplified target gene sequences in the sample is doubled with each PCR cycle. Cycle threshold $(\mathbf{C t})$ value is the number of PCR cycles where emitted fluorescence from amplifying reactions exceed a certain limit (Koskinen et al., 2009); the sooner the detection limit is exceeded, the more target DNA the sample contains. Consequently, the lower the Ct value, the higher the amount of DNA of the amplified pathogen in the sample. Maximum number of cycles per run is 40.0 and the cutoff for a positive result is $\mathrm{Ct}$ value 37.0 (Koskinen et al., 2009). A typical PCR test result includes a list of all detected microbes and their $\mathrm{Ct}$ values $(\mathrm{Ct} \leq 37.0)$, semiquantitative amounts of detected DNA $(+/++/+++)$ based on the $\mathrm{Ct}$ values, or both.

During IMI, when invading microbes reach a certain critical level in the mammary gland, several immunological responses are initiated; milk SCC increases and invading microbes are phagocytosed and killed or their function weakened by different substances secreted in milk (Rainard and Riollet, 2006). Intensity of the inflammatory reaction depends on the causative pathogen (Schukken et al., 2011; Simojoki et al., 2011). The inflammatory reaction in the quarter seen as an increased milk SCC will be resolved slower than IMI (Pyörälä, 1988). A high percentage of growth-negative culture samples in IMI has been widely reported (Bradley et al., 2007; Koivula et al., 2007; Bexiga et al., 2011). During IMI, viable bacterial cells that do not 
grow on agar plates but induce an inflammatory reaction in the quarter may be present. It may be assumed that the proportions of viable bacterial cells compared with those of dead or damaged bacterial cells during IMI change constantly and all invading microbes may be eliminated. On the contrary to conventional culturing, PCR can detect DNA of growth-inhibited or dead target microbes. One concern with the use of PCR in mastitis diagnostics has been the possibility that a portion of the detected pathogen DNA may originate from dead bacteria.

Follow-up of cure from IMI has been assessed using conventional bacteriological culture and measuring indicators of inflammation such as SCC both in natural (Pyörälä, 1988) and experimental (Bannerman, 2009; Simojoki et al., 2011) infections. No studies have been published where elimination of bacteria in experimentally induced bovine IMI has been monitored with multiplex real-time PCR. The aim of the current study was to describe elimination of bacteria in experimentally induced IMI on the quarter level using conventional bacterial culture (BC) and multiplex real-time PCR assay (later referred as PCR). Secondarily, PCR results based on 2 different cutoff values (Ct 37.0 and 34.0) were compared with $\mathrm{BC}$ results. We hypothesized that experimentally induced CNS IMI will appear to be eliminated faster when milk samples are tested with $\mathrm{BC}$ than with PCR.

\section{MATERIALS AND METHODS}

The experimental part of this study and microbiological cultures were carried out at the Department of Production Animal Medicine, University of Helsinki, Finland. All samples were collected and examined by authors H. Hiitiö, H. Simojoki, and S. Taponen. Detailed description of the experimental challenge and the inoculation protocol are described in Simojoki et al. (2011). The study was approved by The Ethics Committee of Helsinki University.

\section{Milk Sampling Protocol and BC}

Eight primiparous (1 Holstein and 7 Ayrshire), clinically healthy mid-lactation cows were used in the original study (Simojoki et al., 2011). Sixteen quarters were challenged with either Staphylococcus epidermidis or Staphylococcus simulans. Samples from 2 S. simulansinfected quarters were not available for the PCR analysis in this study, comprising 8 quarters infected with Staphylococcus epidermidis and 6 quarters infected with S. simulans. Elimination of the bacteria was assessed with conventional BC and PCR (PathoProof Mastitis Complete-12 Kit, Thermo Fisher Scientific, Waltham,
MA). The CNS strains used in our experiment were originally isolated from naturally occurring, persistent subclinical IMI from 2 different cows. The strains were identified with amplified fragment length polymorphism (AFLP; Taponen et al., 2007). Characteristics of the CNS strains, preparation of inoculates, and the challenge protocol have been described in detail in Simojoki et al. (2011).

The study comprised 4 study periods. One study period included a 2-wk cycle with an experimental challenge and 20 milk samplings of the quarter. This was followed by a 2 -wk washout period. Four cows were infected at a time, 2 with $S$. epidermidis and 2 with $S$. simulans. A week before the experimental challenge, the test quarters were sampled and cultured twice, 24 $\mathrm{h}$ apart, with no bacterial growth detected in $\mathrm{BC}$ and with mean SCC of $20 \times 10^{3}$ cells $/ \mathrm{mL}$ of milk. If the cow had bacterial growth in the test quarter at the last sampling of the first challenge, it was treated with antimicrobials during the wash-out period (Simojoki et al., 2011). These treated cows were tested in 3 consecutive samplings, taken $24 \mathrm{~h}$ apart with $\mathrm{BC}$, just before the second challenge period to ensure that the quarters were free from bacterial infections. No infected quarter served again as a test quarter.

In the experimental challenge, 1 udder quarter of each cow was inoculated with either $S$. simulans or $S$. epidermidis. Each inoculate contained $5.7 \times 10^{6} \mathrm{cfu}$ in $7 \mathrm{~mL}$ of saline. Aseptic milk samples for bacteriological culture, PCR testing, and for SCC determination were collected before milking at $0,4,6,12,21,27,30,36,45$, 54, 69, 78, 93, 102, 117, 126, 141, 168 (7 d), 240 (10 d), and $336 \mathrm{~h}(14 \mathrm{~d})$ postchallenge $(\mathbf{P C})$. A volume of 100 $\mu \mathrm{L}$ was plated on blood agar (Tammer-Tutkan Maljat Oy, Tampere, Finland), resulting in a detection limit of $10 \mathrm{cfu} / \mathrm{mL}$ of milk. Serial dilutions of each sample were also done to enable accurate counting of the colonies. All colonies on the plates were visually observed and counted from every dilution. Colonies were identified as CNS by standard procedures (Middleton et al., 2017). If some colonies differed morphologically in visual examination, they were identified with API Staph ID 32 test (bioMérieux, Marcy-l'Étoile, France; Simojoki et al., 2011). The API Staph profiles were compared with the original API Staph profiles of the S. epidermidis and $S$. simulans strains used in challenge (Taponen et al., 2007).

The definition for a spontaneously cured quarter was that no inoculated staphylococcal species, nor any other bacterial species, were detected in $\mathrm{BC}$ in the last sampling at $336 \mathrm{~h}$ PC. If the inoculated staphylococcal species was detected in the last culture, the quarter was defined persistently infected. Aliquots of the milk samples were stored frozen at $-80^{\circ} \mathrm{C}$ for PCR. 


\section{Multiplex Real-Time PCR}

Milk samples from 8 S. epidermidis-infected quarters and 6 S. simulans-infected quarters were tested with PCR (PathoProof Mastitis Complete-12 Kit, Thermo Fisher Scientific). The oligos of the Complete-12 Kit are designed to detect DNA of Corynebacterium bovis, Enterococcus faecalis/faecium, Escherichia coli, Klebsiella oxytoca/pneumoniae, Serratia marcescens, Staphylococcus aureus, Staphylococcus spp., Streptococcus agalactiae, Streptococcus dysgalactiae, Streptococcus uberis, and Peptoniphilus indolicus or Trueperella pyogenes or both. The milk sample volume for DNA extraction was $350 \mu \mathrm{L}$, which was concentrated to $100 \mu \mathrm{L}$ in the elution step of the extraction protocol. Twenty microliters of extracted DNA was used in PCR, divided into 4 reactions, leading to a volume of $5 \mu \mathrm{L}$ used in every reaction. Each reaction in the Complete-12 kit includes 3 targets and an internal amplification control. The non-aureus staphylococci were not identified at species level in PCR. Cycle threshold values were measured up to 40.0 and the results converted into genome copy (gc) numbers to achieve a more understandable description of the elimination curve of the bacteria to be compared with culture results. Numbers of genome copies per reaction were provided by Thermo Fisher Ltd. per the authors' request using the following formula: genomic copy number per reaction $=10^{(\mathrm{Ct}-\mathrm{x})} / \mathrm{y}$, where $\mathrm{Ct}=$ cycle threshold value, $\mathrm{x}=$ slope of a standard curve, and $\mathrm{y}=$ intercept of a standard curve. Genomic copy number per milliliter $=$ genome copies per reaction $\times$ 57 , as only 1:20 of the original milk sample volume is used. Consequently, the lower the $\mathrm{Ct}$ value, the higher the amount of the amplified pathogen. The formula does not take into account possible differences in target gene or DNA fragment copy numbers within a genome.

\section{SCC}

Somatic cell counts from all quarter milk samples was monitored as an indication of inflammation. The SCC was determined by a fluoro-optical method using the Fossomatic instrument (Foss Electric A/S, Hillerød, Denmark) at Valio Ltd. Laboratories, Helsinki, Finland. The upper quantification limit of SCC analysis was $10,000 \times 10^{3}$ cells $/ \mathrm{mL}$.

\section{Data Analysis}

To describe the elimination of bacteria and for correlation calculations, all detections from cultures and PCR were recorded. The detection limit for culture was $10 \mathrm{cfu} / \mathrm{mL}$. For PCR, all positive results with the maximum Ct of 40.0 were recorded and translated into ge- nome copies per milliliter. Correlations were calculated between colony-forming units and genome copies per milliliter using Spearman's rank correlation coefficient, as the data were not normally distributed. Correlations were calculated for the whole 2 -wk period, but also for the acute phase of 0 to $36 \mathrm{~h}$, the subsequent phase up to 1 wk (45-168 h), and the second week including samplings at 240 and $336 \mathrm{~h}$ PC. Correlations between colony-forming units and genome copies per milliliter were calculated for samples originating from quarters infected with Staphylococcus spp. (i.e., both species together, $\mathrm{n}=280)$ and for $S$. simulans $(\mathrm{n}=120)$ and $S$. epidermidis $(\mathrm{n}=160)$ separately. Correlations between colony-forming units and genome copies per milliliter for both species were also calculated separately for each individual cow. Due to variation between cows, low statistical power due to small sample size and descriptive nature of the study, no $P$-values for the correlation coefficients are reported.

Additionally, 2 PCR cutoff values, Ct 34.0 and 37.0, were tested for Staphylococcus spp. These Ct values were chosen because Ct 34.0 has previously been suggested to be more appropriate for Staphylococcus spp. in routine use (Hiitiö et al., 2016), although Ct 37.0 is currently the routine cutoff in the PathoProof Mastitis Assay. Each result $(\mathrm{n}=280)$ was interpreted as IMI positive (1) or negative (0). Culture result was positive if $\geq 1$ cfu of inoculated Staphylococcus species were detected in $\mathrm{BC}$ (detection limit $10 \mathrm{cfu} / \mathrm{mL}$ ). The PCR result was interpreted as positive if the $\mathrm{Ct}$ value for Staphylococcus spp. was $\leq 37.0$ or $\leq 34.0$. Agreement between BC and PCR results for both cutoffs were tested using Cohen's kappa ( $\kappa)$. The agreement was calculated for the whole 2 -wk study period $(0-336 \mathrm{~h})$ and for the 3 sampling periods at 0 to 36,45 to 168 , and 240 to 336 h PC. Kappa values of 0 to 0.20 were defined as slight, 0.21 to 0.40 as fair, 0.41 to 0.60 as moderate, 0.61 to 0.80 as substantial, and 0.81 to 1.00 as almost perfect agreement (McHugh, 2012). Statistical analyses were carried out with IBM SPSS Statistics for Macintosh, Version 24.0. (IBM Corp., Armonk, NY).

\section{RESULTS}

A total of 280 samples from 14 quarters were cultured and tested by PCR and had milk SCC recorded. A total of 160 samples originated from 8 quarters infected with $S$. epidermidis and 120 samples from 6 quarters infected with S. simulans.

\section{$B C$}

Growth of inoculated staphylococcal strains was detected in all test quarters $(\mathrm{n}=14)$, indicating a pres- 


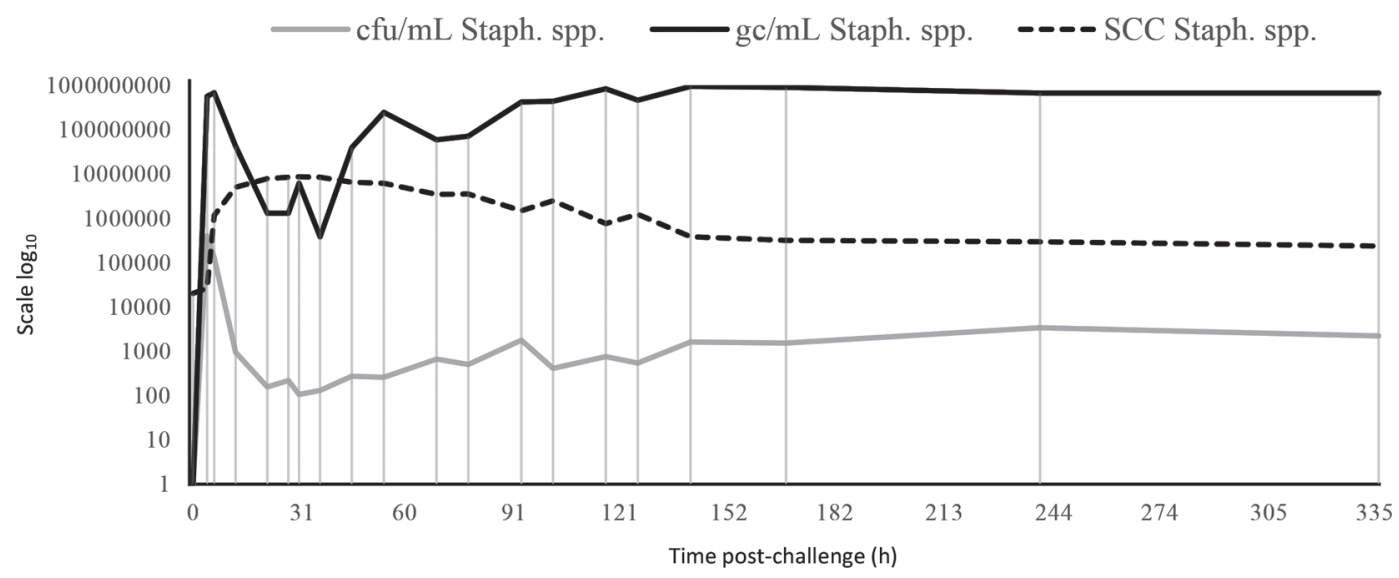

Figure 1. Mean bacterial colony counts $(\mathrm{cfu} / \mathrm{mL}$ ) from conventional culture, genome copy numbers $(\mathrm{gc} / \mathrm{mL}$ ) from multiplex real-time PCR, and SCC per milliliter in milk from mammary quarters experimentally infected with Staphylococcus spp. (n = 14) during the 2 -wk (336 h) study period presented on a $\log _{10}$ scale. Vertical lines show time points of milk sampling.

ence of an IMI. Bacterial counts of the quarters were the highest after $4 \mathrm{~h} \mathrm{PC}\left(4.01 \times 10^{5} \mathrm{cfu} / \mathrm{mL} ; 5.60 \log _{10}\right.$ $\mathrm{cfu} / \mathrm{mL})$ and the lowest at $30 \mathrm{~h} \mathrm{PC}\left(1.06 \times 10^{2} \mathrm{cfu} /\right.$ $\mathrm{mL} ; 2.02 \log _{10} \mathrm{cfu} / \mathrm{mL}$; Figure 1). Four quarters out of the 14 showed no bacterial growth in $\mathrm{BC}$ at the last sampling of the 2 -wk study period. Spontaneous bacteriological cure of these 4 quarters was recorded at 54, 336, and 45 h PC (S. epidermidis; in Figure 2A, B, and $\mathrm{D}$, respectively) and at $168 \mathrm{~h}$ PC (S. simulans; Figure $2)$. The other 10 quarters showed bacterial growth at the end of the study period ( 5 out of 8 quarters for $S$. epidermidis and 5 out of 6 quarters for S. simulans) and were defined as quarters with persistent IMI. Mean bacterial counts in colony-forming units and genome copies per milliliter, grouped according to the bacteriological cure, are presented in Figure 3.

\section{Multiplex Real-Time PCR}

The number of genome copies per milliliter for Staphylococcus spp. was the highest at $141 \mathrm{~h} \mathrm{PC} \mathrm{(9.54}$ $\left.\times 10^{8} \mathrm{gc} / \mathrm{mL} ; 8.98 \log _{10} \mathrm{gc} / \mathrm{mL}\right)$ and the lowest at 36 h PC $\left(3.87 \times 10^{5} \mathrm{gc} / \mathrm{mL} ; 5.59 \log _{10} \mathrm{gc} / \mathrm{mL} ;\right.$ Figure 1). Only 1 quarter infected with $S$. epidermidis (cow 1) was classified as negative in PCR at the end of the study, when no genome copies were detected at $336 \mathrm{~h}$ PC (Table 1). Staphylococcal DNA was detected in all other quarters from $4 \mathrm{~h} \mathrm{PC}$ until the end of the study period (Table 1). Number of genome copies in quarters defined cured in BC appeared to be lower than in the quarters defined persistently infected throughout the study period (Figure 3).

If the results were assessed with the routine $\mathrm{Ct}$ cutoff value of 37.0 , the only quarter negative in PCR $(S$. epidermidis, cow 1) would have been reported negative already at $240 \mathrm{~h} \mathrm{PC}$ (Table 1). In addition, with the cutoff of 37.0, 6 quarters had 1 or several negative PCR results during the sampling period (Table 1 ). When using the lower cutoff of 34.0, 2 quarters were negative at $336 \mathrm{~h} \mathrm{PC}$, one of which was still positive in culture (Table 1). Additionally, at least 1 sample of 9 different quarters would have been reported PCR negative during the study period (Table 1). Of the total number of culture-negative samples, 62.5 (Ct 37.0) and 42.8\% (34.0) yielded a positive PCR result for Staphylococcus spp., with most of these samples occurring between 45 and $336 \mathrm{~h} \mathrm{PC}$.

\section{Milk SCC}

In all quarters, milk SCC exceeded 100,000 cells/ $\mathrm{mL}$ between 4 and $12 \mathrm{~h} \mathrm{PC}$ and peaked reaching the upper quantification limit of $10,000 \times 10^{3}$ cells $/ \mathrm{mL}$ at 21 to $36 \mathrm{~h}$ PC (Figure 1), except for 1 quarter with $S$. epidermidis IMI (cow 3 , SCC $988 \times 10^{3}$ cells $/ \mathrm{mL}$ at $36 \mathrm{~h} \mathrm{PC}$ ). The highest SCC in S. epidermidis-infected quarters was recorded at $30 \mathrm{~h} \mathrm{PC}\left(6,792 \times 10^{3}\right.$ cells/ $\mathrm{mL})$. Mean SCC for S. epidermidis-infected quarters at $336 \mathrm{~h} \mathrm{PC}$ was $210 \times 10^{3}$ cells $/ \mathrm{mL}$. In S. simulans-infected quarters the highest SCC $\left(9,013 \times 10^{3}\right.$ cells $\left./ \mathrm{mL}\right)$ was recorded at $36 \mathrm{~h}$ PC. Mean SCC for S. simulansinfected quarters in the final recording at $336 \mathrm{~h} \mathrm{PC}$ was $96 \times 10^{3}$ cells $/ \mathrm{mL}$. At the end of the 2 -wk study period, 2 quarters infected with $S$. epidermidis (cows 1 and 4 ) and 3 quarters infected with $S$. simulans (cows 2,6 , and 8) had SCC $<100,000$ cells/mL. In culturenegative, PCR-positive samples, SCC varied between $10 \times 10^{3}$ and $10 \times 10^{6}$ cells $/ \mathrm{mL}$. 
$\longrightarrow \mathrm{gc} / \mathrm{mL}$

\section{A: Cow 1. S. epidermidis}

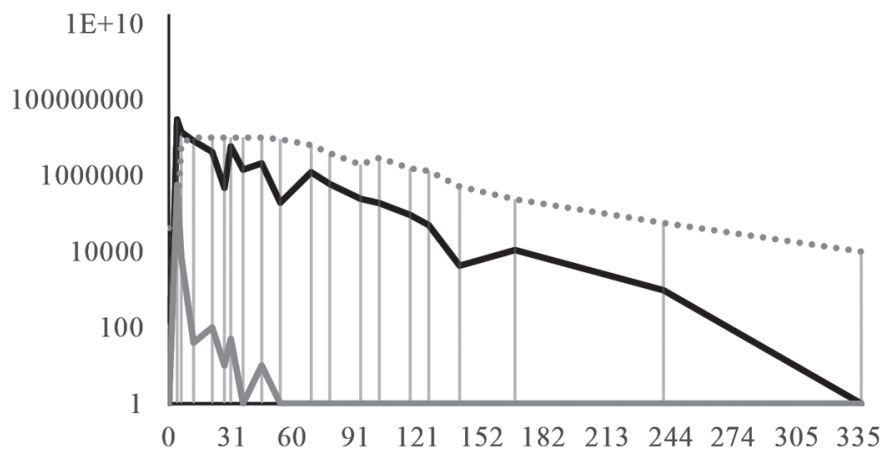

C: Cow 6. S. epidermidis

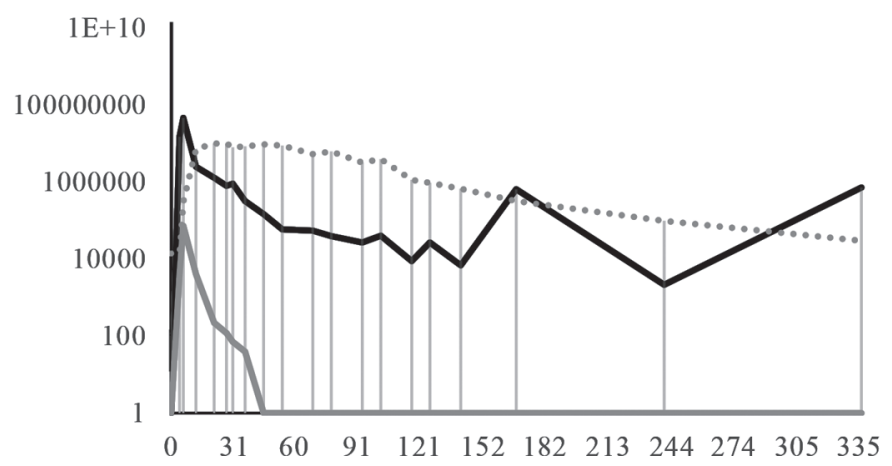

B: Cow 2. S. epidermidis

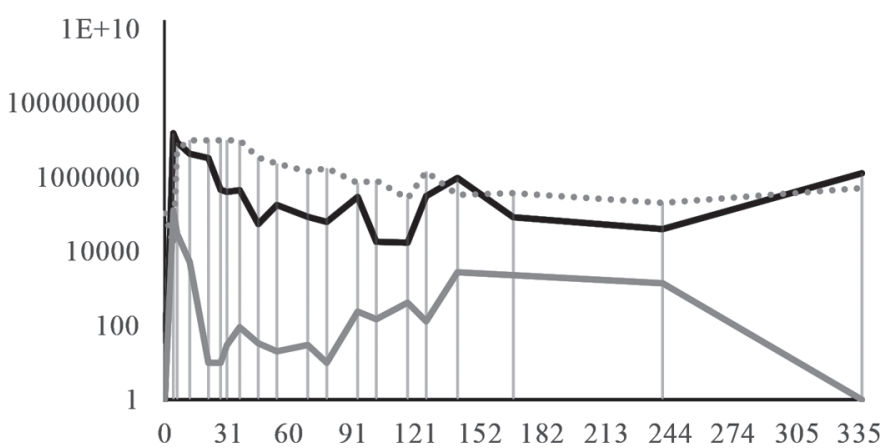

D: Cow 6. S. simulans

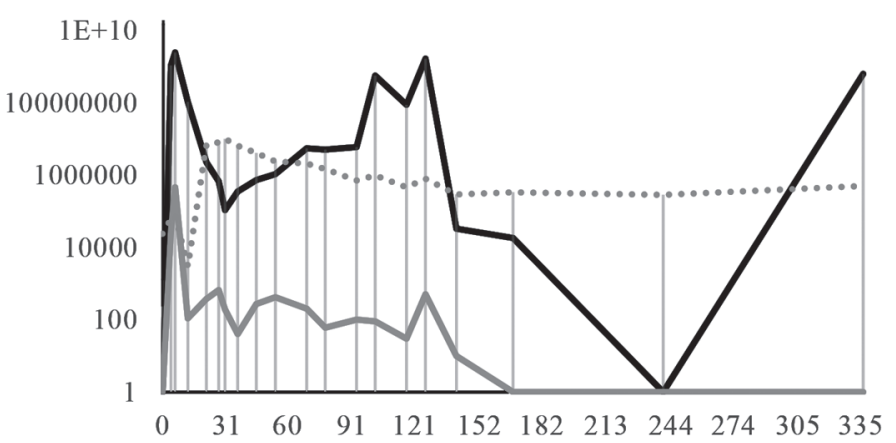

Figure 2. Elimination of Staphylococcus spp. from quarters with bacteriological cure during the 2-wk study period (336 h). Definition for cure was a negative result $(<10 \mathrm{cfu} / \mathrm{mL})$ in the last sampling at $336 \mathrm{~h}$ postchallenge. Bacterial counts were assessed with conventional bacterial culture $(\mathrm{cfu} / \mathrm{mL}$ ) and with multiplex real-time PCR (genome copies; gc/mL). Three of the quarters were infected with Staphylococcus epidermidis (A-C) and one with Staphylococcus simulans (D). Milk SCC of the quarters is also shown. Vertical lines in panels show milk sampling time points.

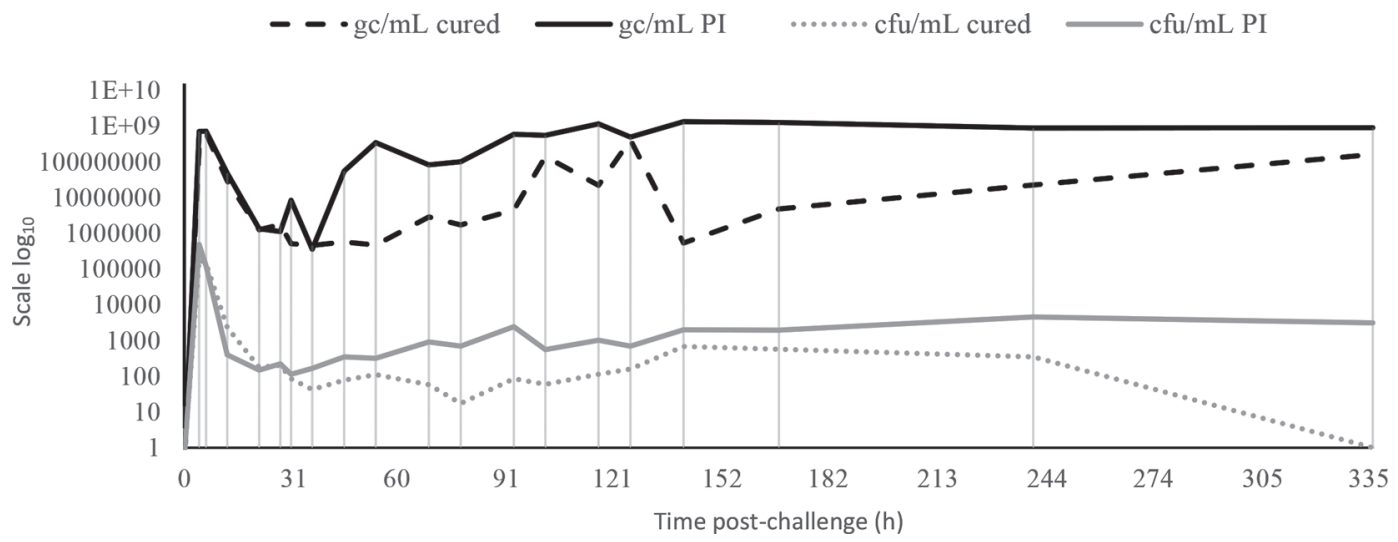

Figure 3. Bacterial numbers in experimentally infected quarters defined cured $(n=4)$ or persistently infected (PI; $n=10)$ during the 2 -wk study period. Definition for cure was a negative culture result $(<10 \mathrm{cfu} / \mathrm{mL})$ in the last sampling at $336 \mathrm{~h}$ postchallenge. Bacterial numbers were assessed with conventional bacterial culture (cfu/mL of milk) and multiplex real-time PCR (genome copies; gc/mL of milk) on a log10 scale. Vertical lines represent the time points of milk samplings. 
HIITIÖ ET AL.

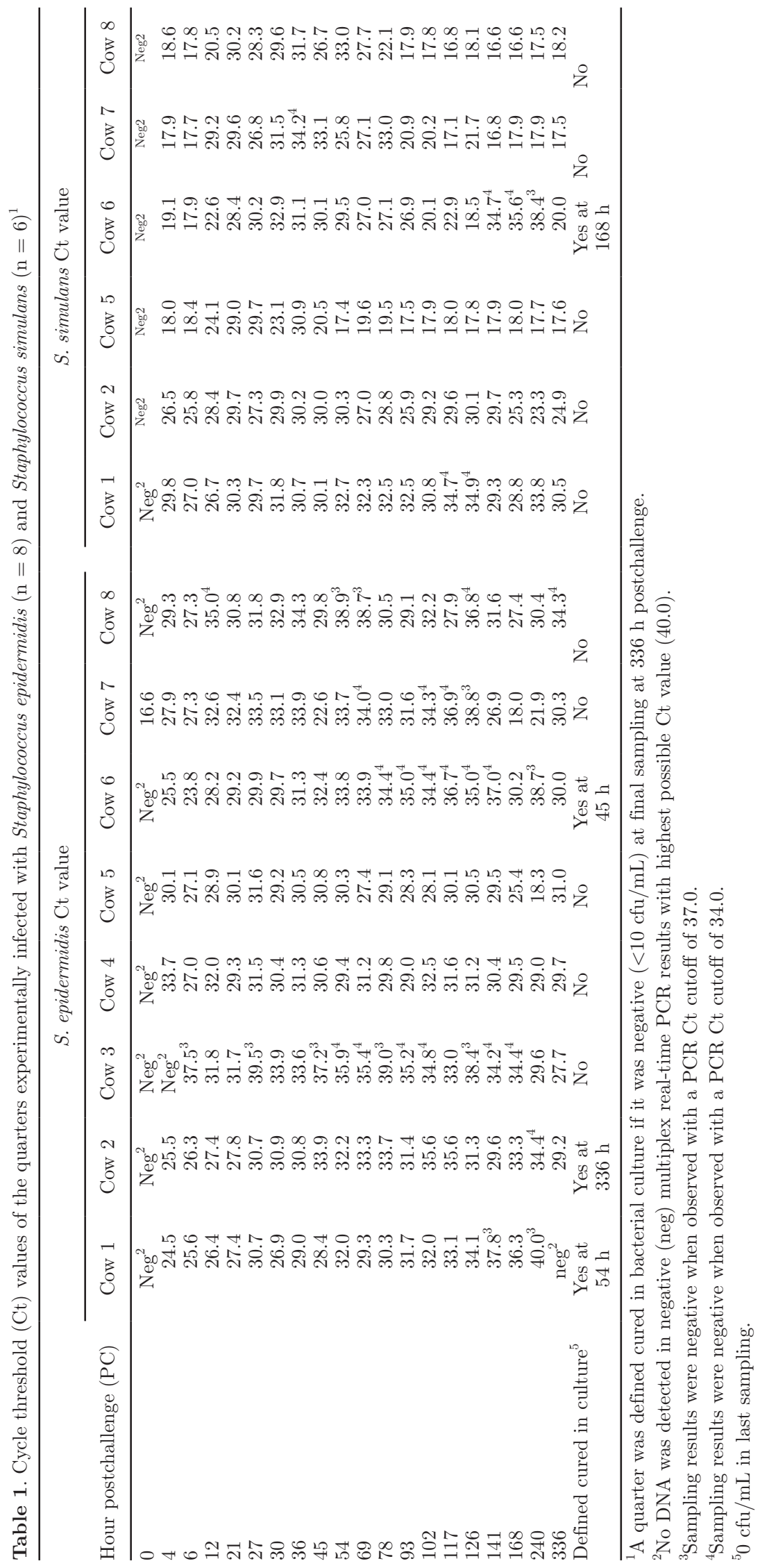




\section{Comparison of $B C$ and PCR Results}

Genome copy number and colony-forming units per milliliter behaved similarly for the first $36 \mathrm{~h}$ PC (Figure 1). After this, genome copies gradually increased peaking after $140 \mathrm{~h} \mathrm{PC}$, exceeding the genome copies numbers recorded at the first samplings of the study. Number of colony-forming units also increased after the first $36 \mathrm{~h} \mathrm{PC}$, but never reached peak numbers seen at 4 to $6 \mathrm{~h} \mathrm{PC} \mathrm{(Figure} \mathrm{1).}$

Correlation between colony-forming units and genome copies per milliliter for Staphylococcus spp. was 0.55 for the whole study period, 0.68 for the first 36 h, 0.44 for 45 to $168 \mathrm{~h} \mathrm{PC}$, and 0.46 for 240 to $336 \mathrm{~h}$ PC. Correlation between culture and PCR results for S. epidermidis was 0.60 and 0.55 for $S$. simulans for the whole 2 -wk period. Correlations varied between cows and individual quarters; for S. epidermidis-infected quarters in cows 1 to 8 , correlations were $0.80,0.35$, $0.70,0.59,0.70,0.81,0.31$, and 0.69 , respectively. For quarters infected with $S$. simulans, cows 1,2 , and 5 to 8 , correlations were $0.67,0.75,0.66,0.57,0.55$, and 0.85 . Agreement between the 2 tests for detecting Staphylococcus spp. was classified as almost perfect $(\kappa=0.85)$ for the first $36 \mathrm{~h}$ with Ct cutoff 37.0 and substantial $(\kappa=0.76)$ with cutoff 34.0 . For the whole study period (0-336 h), the agreement was moderate (Table 2).

\section{DISCUSSION}

\section{Elimination of the Bacteria Determined with $B C$ and PCR}

Ours was the first study where an experimentally induced bovine IMI was monitored with PCR in addition to conventional culture. We hypothesized that IMI would appear to resolve faster when milk samples were tested with $\mathrm{BC}$ compared to testing with PCR. This hypothesis was supported by the data from the 4 quarters that were classified as cured and where no Staphylococcus spp. could be cultured at the end of the follow-up period. The DNA of Staphylococcus spp. was detected by PCR for several days after the time point when bacteria was no longer detected with conventional culture (Table 1, Figure 2). Amplification of DNA sequences with PCR is possible also from dead and growth-inhibited microbes (Koskinen et al., 2009; Taponen et al., 2009) as long as the target DNA sequences are intact. To the best of our knowledge, no information on how long target DNA for PCR remains intact in milk or inside the phagocytic cells is available. On the other hand, a no-growth result in $\mathrm{BC}$ is not enough to claim that viable bacterial cells would not be present in the milk sample. Milk from IMI quarters

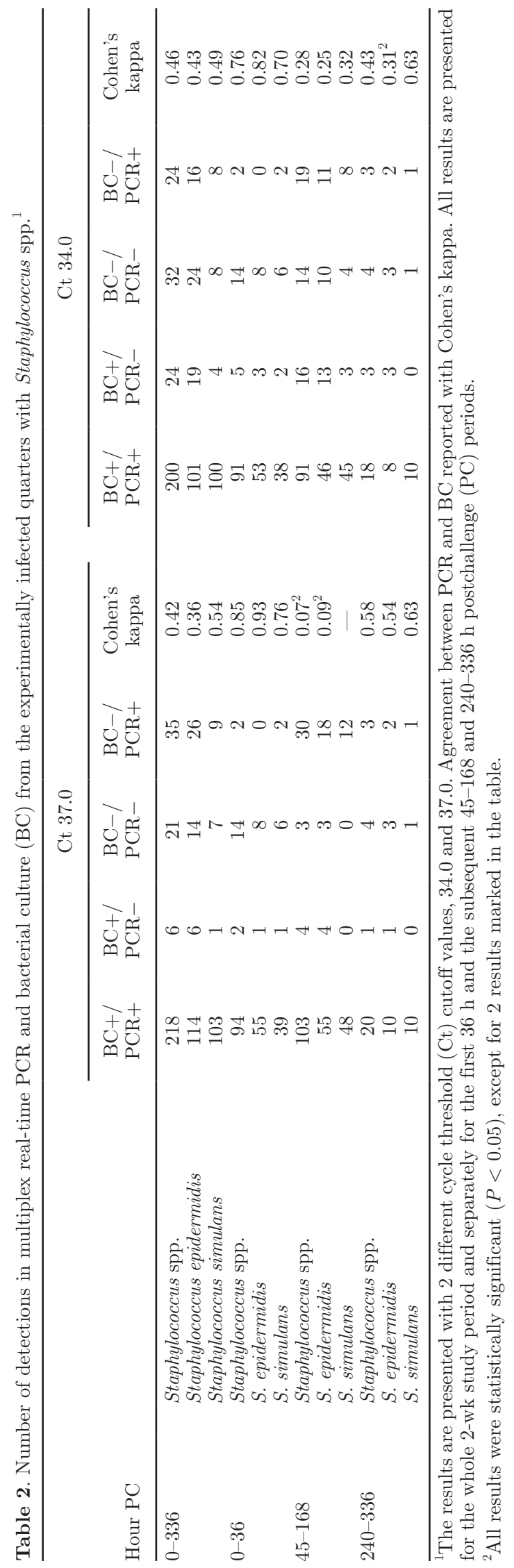

Journal of Dairy Science Vol. 101 No. 6, 2018 
contains several substances that may inhibit bacterial growth on agar plates (Rainard and Riollet, 2006). Increasing the volume of the milk to be cultured has been reported to improve the sensitivity of the method at least for S. aureus (Walker et al., 2010). We used $100 \mu \mathrm{L}$ of inoculum instead of the routine $10 \mu \mathrm{L}$, which increased the sensitivity of the $\mathrm{BC}$ results. The host as well as bacterial species may also affect the course of infection and viability of bacteria (Schukken et al., 2011; Simojoki et al., 2011).

Direct comparisons between culture and PCR are difficult, as microbial counts presented with genome copies and colony-forming units per milliliter are estimations. The number of targeted microbes in multiplex real-time PCR is not exact. The target sequences in the microbial genome may be present in several loci, and the number of genome copies is a result of an external standard curve; real-time PCR may thus be considered a semiquantitative method (Pereira et al., 2008). In BC, colony-forming units are calculated instead of actual number of bacteria. Despite these biological facts the figures of colony-forming units and genome copies per milliliter were surprisingly similar for the first $36 \mathrm{~h} \mathrm{PC}$ (Figure 1) and the correlation between colony-forming units and genome copies per milliliter was relatively strong, even though considerable variation between cows was observed. The strong decline in bacterial counts seen around 12 to $36 \mathrm{~h}$ PC with both methods can be explained by efficient destruction of invading bacteria and their DNA by the immune reaction of the mammary gland (Paape et al., 2003; Mehrzad et al., 2004; Rainard and Riollet, 2006).

After the first $36 \mathrm{~h}$, bacterial numbers, as assessed with both diagnostic methods, increased again. At this point colony-forming units stayed below the peak recorded at the beginning of the IMI, but genome copies exceeded the peak numbers (Figure 1 and 2). After 100 $\mathrm{h}$ PC, the bacterial counts did not fluctuate anymore, achieving a steady state, where genome copies were consistently several times higher than colony-forming units. It is possible that the relatively higher genome copies from PCR compared with colony-forming units from culture was due to PCR amplifying DNA from all staphylococcal cells, including living and constantly dividing, growth-inhibited, and dead cells. In culture, only viable and fit cells are detected. Coagulasenegative staphylococci have been shown capable of adhering to and some strains also internalizing into bovine mammary epithelial cells in vitro (Hyvönen et al., 2009). Based on the shedding curves of the persistent infections, we speculated that possible adhesion of the staphylococci took more than $36 \mathrm{~h}$, after which steady bacterial counts were eventually reached, as observed with both methods. In the cured quarters, host response and the immune defense of the quarter were able to eliminate the IMI.

\section{Agreement Between BC and PCR with Different Ct Cutoff Values}

In addition to following the elimination of bacteria from the inoculated quarters, we also observed the results from the diagnostic point of view, assessing agreement of $\mathrm{BC}$ and PCR on detecting IMI at different time points $\mathrm{PC}$. For the first $36 \mathrm{~h} \mathrm{PC}$, the agreement between BC and PCR was almost perfect (Table 2), but decreased into a moderate level of agreement toward the end of the study period. For the whole 336-h study period, the agreement between the 2 tests was moderate with both Ct cutoff values (Table 2). After the acute phase, many milk samples were culture negative but still PCR positive, which caused a lower level of agreement between $\mathrm{BC}$ and PCR toward the end of the study period. We reported a corresponding level of agreement between BC and PCR diagnosis $(\kappa=0.44)$ for Staphylococcus spp. in natural IMI (Hiitiö et al., 2015). It seems that only moderate agreement between $\mathrm{BC}$ and PCR can be achieved in natural infections, as the course and duration of IMI is not known. If the milk sample is taken several days after the acute phase, the positive PCR result may originate from microbes no longer capable of growing on culture plates (Figure 2).

Using the lower Ct cutoff of 34.0, the number of PCR results classified as negative was higher than when using the higher Ct cutoff of 37.0 (Table 1). Several consecutive negative PCR results during the study period with Ct cutoff of 34.0, especially in S. epidermidis-infected quarters, were seen, likewise for cows with persistent IMI (based on BC) at $336 \mathrm{~h}$ PC. Our results showed that during the acute phase with high colony counts in $\mathrm{BC}$, low Ct values in PCR, and high milk SCC, the diagnosis of IMI seems reliable with both bacteriological methods. After the acute phase of staphylococcal infection, with Ct values between 34.0 and 37.0 and SCC decreasing, the results are more difficult to interpret. It is impossible to predict the course of the IMI, it may be cleared or remain persistent, as seen in Table 1, which is very likely the situation also in natural infections. Thus, it is difficult to interpret a single PCR result from naturally occurring IMI with a small amount of Staphylococcus spp. DNA, which can originate from a persistent IMI or, maybe more likely, from the teat canal or teat skin (Hiitiö et al., 2016). In addition, PCR does not identify staphylococci on species level. Targeting all non-aureus staphylococci from milk samples, not related to IMI, could potentially increase the amount of detected Staphylococcus spp. in routine samplings in 
naturally occurring IMI. In this experimental study, we did not identify any additional staphylococcal species in the cultures. Consequently, it is likely that a proportion of non-aureus staphylococcal DNA from species other than the inoculated experimental strains was minimal in the samples.

Pathogen-specific Ct values to interpret results have been suggested by several authors to improve the diagnostic reliability of PCR assay in routine mastitis diagnostics (Cederlöf et al., 2012; Mahmmod et al., 2017; Steele et al., 2017). For Staphylococcus spp., a lower Ct cutoff value has been suggested (Hiitiö et al., 2016). In the current study, a lower percentage of the culture-negative samples were positive for staphylococcal DNA in PCR with Ct cutoff 34.0 than with 37.0, which supports the previous suggestions. Here, we used a very low detection limit $(10 \mathrm{cfu} / \mathrm{mL})$ for a positive culture result for Staphylococcus spp. because of the experimental nature of the study. The results are thus not fully comparable with previous studies with natural IMI and higher detection limits.

\section{Evaluation of Cure}

In the present study, the mean SCC of quarters defined as cured by culture remained above 100,000 cells/ $\mathrm{mL}$. Cure of mastitis can be defined as recovery from inflammation, where SCC of the quarter is decreased to normal levels, under 100,000 cells/mL (International Dairy Federation, 2013), with or without a bacteriological cure (International Dairy Federation, 2011). Inflammatory reaction of the mammary quarter is generally resolved within 3 wk if infection is eliminated (Pyörälä, 1988). In our study, milk SCC of the only quarter defined as cured in both BC and PCR (Figure 2A) decreased to the level of a healthy quarter (57,000 cells/ $\mathrm{mL}$ of milk) during the study period; this indicates that not only the infection but also the inflammation was dissolved from this quarter. In the 3 other quarters defined bacteriologically cured by $\mathrm{BC}$ but not by PCR (Figure 2B-D), the SCC was 517,000 (B), 30,000 (C), and 495,000 (D) cells/mL, respectively, at $336 \mathrm{~h} \mathrm{PC}$, indicating continuous inflammation for $\mathrm{B}$ and $\mathrm{D}$. The cure of the cow presented in Figure 2B looks questionable, as it shed relatively high amounts of $S$. epidermidis and a negative culture result was obtained only in the last sampling, with SCC indicating continuing inflammation. This cow, however, was classified as cured by $\mathrm{BC}$ according to the check-up samples before the next challenge. The current study would have benefited from a larger sample size and from more quarters with nonpersisting infection, as well as monitoring quarters for a longer period, which we unfortunately were not able to perform. It is also noteworthy that the detection limit used in the current study for positive Staphylococcus spp. in $\mathrm{BC}$ was very low, $10 \mathrm{cfu} / \mathrm{mL}$, whereas in routine mastitis diagnostics using $\mathrm{BC}$ the standard volume plated is $10 \mu \mathrm{L}$ and, thus, the minimum detection limit is $100 \mathrm{cfu} / \mathrm{mL}$ (Middleton et al., 2017). A higher cutoff for IMI, $300 \mathrm{cfu} / \mathrm{mL}$ or even more, has been used for minor pathogens such as CNS (Pitkälä et al., 2004; Østerås et al., 2006). If a higher limit had been used in the current study, more quarters would likely have been declared bacteriologically cured with BC.

Evaluation of cure should always rely both on bacterial analysis and milk SCC (or another indicator of inflammation). It can be speculated that a PCR result with low amount of staphylococcal DNA may more likely be a true infection if SCC is high than if SCC is low. Kalmus et al. (2014) used multiplex real-time PCR in diagnosing bacterial cure in a study evaluating the efficacy of 2 treatments of clinical mastitis (Kalmus et al., 2014). Outcome of the treatments was assessed 3 to $4 \mathrm{wk}$ after the beginning of treatment and those authors reported that bacteriological cure was up to 20 to $30 \%$ lower than previously reported (Taponen et al., 2003; Apparao et al., 2009). Kalmus et al. (2014) suggested that PCR could explain the lower cure rates; our results here support this assumption.

Our study is the first study where an experimental infection was monitored with multiplex real-time PCR in addition to culture. We showed that DNA of the target pathogens may be detected for longer periods with PCR than viable cells in BC. Based on this study, we recommend waiting at least 2 to 3 wk after the onset of mastitis or possible antimicrobial treatment, or until the quarter milk SCC has decreased to a normal level, before taking milk samples for PCR analysis to assess response to treatment. A positive PCR result soon after treatment does not necessarily indicate a treatment failure. Future studies are needed to further assess the association between positive PCR results and indicators of inflammation such as SCC.

\section{ACKNOWLEDGMENTS}

This study was funded by Finnish Veterinary Foundation (Helsinki, Finland), Academy of Finland (Helsinki, Finland), Ministry of Agriculture and Forestry and University of Helsinki (Helsinki, Finland). The authors want to thank Thermo Fisher Scientific laboratory (Vantaa, Finland) for the PCR analyses and Mika Silvennoinen and Jani Holopainen (Thermo Fisher Scientific, Vantaa, Finland) for the expert technical assistance. 


\section{REFERENCES}

Apparao, M. D., P. L. Ruegg, A. Lago, S. Godden, R. Bey, and K. Leslie. 2009. Relationship between in vitro susceptibility test results and treatment outcomes for gram-positive mastitis pathogens following treatment with cephapirin sodium. J. Dairy Sci. 92:2589-2597.

Bannerman, D. D. 2009. Pathogen-dependent induction of cytokines and other soluble 1 inflammatory mediators during intramammary infection of dairy cows. J. Anim. Sci. 87(Suppl.):10-25. https://doi .org/10.2527/jas.2008-1187.

Bexiga, R., M. T. Koskinen, J. Holopainen, C. Carneiro, H. Pereira, K. A. Ellis, and C. L. Vilela. 2011. Diagnosis of intramammary infection in samples yielding negative results or minor pathogens in conventional bacterial culturing. J. Dairy Res. 78:49-55.

Bradley, A. J., K. A. Leach, J. E. Breen, L. E. Green, and M. J. Green. 2007. Survey of the incidence and aetiology of mastitis on dairy farms in England and Wales. Vet. Rec. 160:253-257.

Cederlöf, S. E., N. Toft, B. Aalbaek, and I. C. Klaas. 2012. Latent class analysis of the diagnostic characteristics of PCR and conventional bacteriological culture in diagnosing intramammary infections caused by Staphylococcus aureus in dairy cows at dry off. Acta Vet. Scand. 54:65-71.

Gillespie, B. E., and S. P. Oliver. 2005. Simultaneous detection of mastitis pathogens, Staphylococcus aureus, Streptococcus uberis, and Streptococcus agalactiae by multiplex real-time polymerase chain reaction. J. Dairy Sci. 88:3510-3518.

Hiitiö, H., R. Riva, T. Autio, T. Pohjanvirta, J. Holopainen, S. Pyörälä, and S. Pelkonen. 2015. Performance of a real-time PCR assay in routine bovine mastitis diagnostics compared with indepth conventional culture. J. Dairy Res. 82:200-208.

Hiitiö, H., H. Simojoki, P. Kalmus, J. Holopainen, S. Pyörälä, and S. Taponen. 2016. The effect of sampling technique on PCRbased bacteriological results of bovine milk samples. J. Dairy Sci. 99:6532-6541.

Hyvönen, P., S. Käyhkö, S. Taponen, A. von Wright, and S. Pyörälä. 2009. Effect of bovine lactoferrnig on the internalization of coagulase-negative staphylococci into bovine mammary epithelial cells under in vitro conditions. J. Dairy Res. 76:144-151.

International Dairy Federation. 2011. Suggested interpretation of mastitis terminology. Bull. Int. Dairy Fed. 448:18.

International Dairy Federation. 2013. Guidelines for the use and interpretation of bovine milk somatic cell counts (SCC) in the dairy industry. Bulletin of the International Dairy Federation, 466/2013. International Dairy Federation, Brussels, Belgium.

Kalmus, P., H. Simojoki, T. Orro, S. Taponen, K. Mustonen, J. Holopainen, and S. Pyörälä. 2014. Efficacy of 5-day parenteral versus intramammary benzylpenicillin for treatment of clinical mastitis caused by gram-positive bacteria susceptible to penicillin in vitro. J. Dairy Sci. 97:2155-2164.

Koivula, M., A. Pitkälä, S. Pyörälä, and E. Mäntysaari. 2007. Distribution of bacteria and seasonal and regional effects in a new database for mastitis pathogens in Finland. Acta Agric. Scand. A Anim. Sci. 57:89-96.

Koskinen, M. T., J. Holopainen, S. Pyörälä, P. Bredbacka, A. Pitkälä, H. W. Barkema, R. Bexiga, J. Roberson, L. Sølverød, R. Piccinini, D. Kelton, H. Lehmusto, S. Niskala, and L. Salmikivi. 2009. Analytical specificity and sensitivity of a real-time polymerase chain reaction assay for identification of bovine mastitis pathogens. J. Dairy Sci. 92:952.

Mahmmod, Y. S., I. C. Klaas, and C. Enevoldsen. 2017. DNA carryover in milk samples from routine milk recording used for PCRbased diagnosis of bovine Staphylococcus aureus mastitis. J. Dairy Sci. 100:5709-5716.

McHugh, M. L. 2012. Interrater reliability: The kappa statistic. Biochem. Med. (Zagreb) 22:276.
Mehrzad, J., L. Duchateau, and C. Burvenich. 2004. Viability of milk neutrophils and severity of bovine coliform mastitis. J. Dairy Sci. 87:4150-4162.

Middleton, J. R., L. K. Fox, G. Pighetti, and C. Petersson-Wolfe, ed. 2017. Laboratory Handbook on Bovine Mastitis. 3rd ed. National Mastitis Council, Inc., New Prague, MN.

Østerås, O., L. Sølverød, and O. Reksen. 2006. Milk culture results in a large Norwegian survey - Effects of season, parity, days in milk, resistance, and clustering. J. Dairy Sci. 89:1010-1023.

Paape, M. J., D. D. Bannerman, X. Zhao, and J. W. Lee. 2003. The bovine neutrophil: Structure and function in blood and milk. Vet. Res. 34:597-627.

Pereira, F., J. Carneiro, and A. Amorim. 2008. Identification of species with DNA-based technology: Current progress and challenges. Recent Pat. DNA Gene Seq. 2:187-199.

Phuektes, P., P. D. Mansell, and G. F. Browning. 2001. Multiplex polymerase chain reaction assay for simultaneous detection of staphylococcus aureus and streptococcal causes of bovine mastitis. J. Dairy Sci. 84:1140-1148.

Pitkälä, A., M. Haveri, S. Pyörälä, V. Myllys, and T. Honkanen-Buzalski. 2004. Bovine mastitis in Finland 2001-Prevalence, distribution of bacteria, and antimicrobial resistance. J. Dairy Sci. 87:2433-2441.

Pyörälä, S. 1988. Indicators of inflammation to evaluate the recovery from acute bovine mastitis. Res. Vet. Sci. 45:166-169.

Rainard, P., and C. Riollet. 2006. Innate immunity of the bovine mammary gland. Vet. Res. 37:369-400.

Schukken, Y. H., J. Günther, J. Fitzpatrick, M. C. Fontaine, L. Goetze, O. Holst, J. Leigh, W. Petzl, H.-J. Schuberth, A. Sipka, D. G. E. Smith, R. Quesnell, J. Watts, R. Yancey, H. Zerbe, A. Gurjar, R. N. Zadoks, and H.-M. Seyfert. 2011. Host-response patterns of intramammary infections in dairy cows. Vet. Immunol. Immunopathol. 144:270-289.

Simojoki, H., T. Salomäki, S. Taponen, A. Iivanainen, and S. Pyörälä. 2011. Innate immune response in experimentally induced bovine intramammary infection with Staphylococcus simulans and S. epidermidis. Vet. Res. 42:49.

Steele, N. M., J. H. Williamson, R. Thresher, R. A. Laven, and J. E. Hillerton. 2017. Evaluating a commercial PCR assay against bacterial culture for diagnosing Streptococcus uberis and Staphylococcus aureus throughout lactation. J. Dairy Sci. 100:3816-3824.

Studer, E., W. Schaeren, J. Naskova, H. Pfaeffli, T. Kaufmann, M. Kirchhofer, A. Steiner, and H. U. Graber. 2008. A longitudinal field study to evaluate the diagnostic properties of a quantitative real-time polymerase chain reaction-based assay to detect Staphylococcus aureus in milk. J. Dairy Sci. 91:1893-1902.

Taponen, S., K. Dredge, B. Henriksson, A.-M. Pyyhtiä, L. Suojala, R. Junni, K. Heinonen, and S. Pyörälä. 2003. Efficacy of intramammary treatment with procaine penicillin $\mathrm{G}$ vs. procaine penicillin $\mathrm{G}$ plus neomycin in bovine clinical mastitis caused by penicillinsusceptible, gram-positive bacteria - a double blind field study. J. Vet. Pharmacol. Ther. 26:193-198.

Taponen, S., J. Koort, J. Björkroth, H. Saloniemi, and S. Pyörälä. 2007. Bovine intramammary infections caused by coagulase-negative staphylococci may persist throughout lactation according to amplified fragment length polymorphism-based analysis. J. Dairy Sci. 90:3301-3307. https://doi.org/10.3168/jds.2006-860.

Taponen, S., L. Salmikivi, H. Simojoki, M. T. Koskinen, and S. Pyörälä. 2009. Real-time polymerase chain reaction-based identification of bacteria in milk samples from bovine clinical mastitis with no growth in conventional culturing. J. Dairy Sci. 92:26102617.

Walker, J. B., P. J. Rajala-Schultz, and F. J. DeGraves. 2010. The effect of inoculum volume on the microbiologic detection of naturally occurring Staphylococcus aureus intramammary infections. J. Vet. Diagn. Invest. 22:720-724. 